\begin{tabular}{|c|c|c|}
\hline & Int.J.Curr.Microbiol.App.Sci (2021) 10(11): 362-368 & \\
\hline EXCEI I ENT & $\begin{array}{l}\text { International Journal of Current Microbiology and Applied Sciences } \\
\text { ISSN: 2319-7706 Volume } 10 \text { Number } \mathbf{1 1} \mathbf{( 2 0 2 1 )} \\
\text { Journal homepage: } \underline{\text { http://www.ijcmas.com }}\end{array}$ & 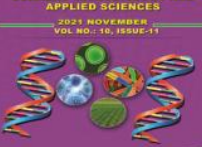 \\
\hline $\begin{array}{l}\text { EXCELLENT } \\
\text { PUBLISHERS }\end{array}$ & & \\
\hline
\end{tabular}

Review Article

https://doi.org/10.20546/ijcmas.2021.1011.041

\title{
Evolution of Teaching Methods in Medical Education Over the Years
}

\author{
Divya Reddy Pannala ${ }^{1}$ and R. Shyamala ${ }^{2} *$ \\ ${ }^{1}$ Department of Forensic Medicine and Toxicology, ${ }^{2}$ Department of Microbiology, AIIMS, \\ Bibinagar, Hyderabad, India \\ *Corresponding author
}

Keywords

Medical Education,

Teaching Methods,

Flipped classroom,

Blended learning,

Interactive teaching

Article Info

Received:

14 October 2021

Accepted:

03 November 2021

Available Online:

10 November 2021

\section{Introduction}

The ultimate aim of Medical education is to provide society with a knowledgeable and skilled health care professional whose priority is patient care above self-interest and who can develop their skills and expertise throughout their career. The medical education system in India is one of the largest in the world with 555 medical colleges in India and 83,175 medical seats in 2021, which increases every year to achieve World Health Organisation
(WHO) recommended doctor to population. Medical education is facing problems and challenges for quality education in the country.

The major drawback of Indian medical education is that, the faculty members in academic medical colleges are not formally prepared for their roles as teachers. It is vital for medical teachers to familiarize themselves with the core concepts of effective teaching practices and information about innovations in 
medical teaching. Successful medical teaching requires the teachers to be able to address their student's needs and understand the variations in their learning styles and approaches. This can be accomplished by creating an optimal teaching-learning environment by utilizing a diversity of teaching methods and styles.

Medical education has changed considerably and will continue to do so with the various scientific advances and societal needs. The previous medical education system in India was based on a subject-centered and timebased curriculum. Most evaluations were summative, with almost no opportunity for feedback from learners. The teaching-learning activities and the assessment methods focused more on knowledge than on attitude and skills.

The new Competency-based medical education (CBME) was introduced to tackle these concerns. The education has now transitioned from teacher-centered to learnercentered. The teachers would also have to face the challenge of altering their attitude and teaching approach to meet the purpose of CBME.As India marches towards an exciting new future of growth and progress, medical education will play a pivotal role in shaping young doctors.

\section{History of Medical Education}

Since ancient times, India is known to have been a civilization, of which medicine and other natural sciences formed a very essential part. Learning about the history of Medical teaching is essential for health professionals as we can learn from both, the mistakes as well as successes of the past.

The origin of Indian system of medicine i.e. the Ayurveda goes back to several years before the birth of Christ. The Charaka Samhita and Sushruta Samhita form the basic treatises even till today, for practitioners of the
Ayurvedic system of medicine in India. The two well-known centers of medical education in ancient times in India were the residential universities of Takshashila and Nalanda in north India. These universities provided wellorganized, institutional training in all aspects of medicine which included both theoretical and practical.

These institutions comprised of "tutorial cells" in which a Guru or preceptor took under him a fixed number of students to train. This arrangement made it possible for the teacher to pay personal attention to the students and oversee their education and training.

With the invasion of the British in India, the western medicine or modern medicine was introduced in this country. Initially the aim was to train apprentices with basic qualification to help the army medical personnel. But, it in the year 1835 a more comprehensive system of training was started in India. The Calcutta Medical College was first established in 1835 to address the increasing need for health professionals in the country. In 1857, after the establishment of the three Universities in major cities of Calcutta, Bombay, and Madras, medical education was taken over by other Universities, which trained and granted the qualifications of a Licentiate in Medicines and Surgery (the L.M.S.) and the Bachelor of Medicine and Master of Surgery to practice medicine.

Medical education in post-independent India faced considerable challenges. In 1947, there were on an average less than 2 doctors per government institution. Medical education suffered greatly due to the vast deficiency in doctors. Several calls for curricular reform have been made since then. The Shrivastav Committee advocated reorientation of medical education by national priorities and needs in 1972. In 1986, the Bajaj Committee asked for 
the establishment of an educational commission for health sciences and also noted that medical college faculty, though efficient in their clinical specialties, were deficient as teachers and educators.

\section{Traditional Methods of Teaching}

Chalk and Talk Method: A chalk talk is a monologue presentation usually done with chalk on black board or with markers on a whiteboard. It is a way to generate ideas, assess learning and solve problems. The traditional and the most frequently used method for teaching anatomy of human body is the chalk and board method. Chalkboard aid is inexpensive and is easy to erase and reuse. It also allows the students to keep up with the teacher. The main disadvantage of this method is that to draw accurate diagrams on black board with chalk is not easy and it is more time consuming. Sometimes, a few difficult medical terminologies are not easily conveyed to the students because of pronunciation, spelling problems or poor visibility

A didactic of instruction in which information is passed on directly from student. Teaching is often used for teaching basic subjects in medicine and instructing students. It is characterized by, structured lesson plans with specific learning objectives where the teachers use this approach to keep their lessons well organized, to present information to students directly face to face. Students learn from these lectures by taking notes and asking questions. An important aspect of the didactic teaching is consistent learning schedules, which change little from day to day. Pedagogy: It is the act of teaching. It includes demonstration, explanation, observation and hands-onexperience. This is a process-oriented technique in which, the teacher demonstrates a concept while the students make observations to learn more about them. Explanation enhances their learning experience. Hands-on learning is a strategy that emphasizes learning things by practicing doing them. It is commonly practiced in medical education during clinical postings and internship.

\section{Modern Methods of Teaching}

\section{E-Teaching}

E-learning provides possibilities for devising new educational tools, for learning by interactivity, self-paced study and easy access. E-learning has become a standard teaching approach in recent times in medical education, especially during COVID pandemic. Elearning is more student friendly as it provides easier adaptability and increases flexibility. Online e-learning was a helpful tool for meeting educational needs during the pandemic. Various digital platforms such as Google Classroom, Zoom, Cisco Webex, Free Conference call, Microsoft Teams and others were used to conduct online classes. Online teaching requires teachers to improve their competency in three major areas i.e. content knowledge, pedagogy and technology.

\section{Blended Teaching}

Method of combining both electronic and face-to-face learning is called as blended learning. This method is an instructional approach that uses digital strategies in tandem with the traditional practices in the classroom. The teacher can draw from a comprehensive toolbox of traditional and digitally enhanced strategies to best meet the needs of their students.

\section{Flipped classroom}

In the flipped classroom, students prepare for class by doing pre-work prior, usually with the help of video lecture. Then they come to the class to solve cases, engage in teamwork and do further research. With the pre-work, 
students watch the video lecture in an environment of their preferred choice keeping with their own pace. They can review the concepts they do not understand as many times as needed. Later, they come to the classroom to learn beyond the basics to develop skills that cannot be taught in a simple didactic lecture.

\section{Mentor Teaching}

It is an interactive method of transfer of knowledge that takes place between people with different levels of experience and the In this method, knowledge, skills, and experience of senior is shared with newer or less experienced members in order to advance their career. This can include various types like the one-to-one, group or peer mentoring.

Problem based Teaching: It is a modern teaching method with small groups of students and a teacher/facilitator. During the sessions, learners discuss various case studies, deliberate on possible differential diagnosis, confer learning goals and organize further investigations required. A Problem Based Learning cycle should conclude with students, analyzing and reflecting on the concepts learnt during the session. The role of a facilitator role is challenging for teachers as they have to work to maintain interest and motivation level among the group by asking open ended questions and resolving any conflicts that arise.

\section{Clinical simulation}

The use of simulation has a wide variety of usage, from the simple duplication of body parts to complex human interactions depicted by simulated patients replicating various diseases symptoms and physiological parameters. The recent advances have made affordable technologies easily available that permit the replication of such clinical events to permit the engagement of learners in a realistic and meaningful way. This also provides a safety-conscious setting where simulation gives a means of risk-free learning experience in critical or rare scenarios.

\section{Interactive Teaching}

This is a form of communicative activity in which students are actively involved in the learning process. This method focuses on student's needs. The teacher's role here is directed towards achieving the goals of students based on their interests and abilities. The lessons are planned which includes several interactive activities and assignments. The activities include role-plays, imitations, excursions, inviting experts, brain storming, case analysis, etc.

In this modern era of increased and improved information technologies, there has been a drastic change in the attitudes of both the teacher and the student in medical education. With the latest change and implementation of Competency Based Curriculum in Medical Education, the educator has to keep up with the pace of changing needs of the learner.

To identify these needs, the National Medical commission had also made it compulsory for teachers in medical colleges to undergo training workshops as a part of the improvement. In latest times, various new and innovative teaching methods are being introduced to enhance the teaching-learning experience and to systematically train the students to be competent doctors.

E-learning has been underutilized in the past, especially in countries like India. However, COVID-19 pandemic has forced everyone to rely on technology for education. Majority of the studies showed that faculty members considered a lecture delivered through elearning to be more time consuming and can 
lead to student monitoring difficulties thereby reducing their interest in contrast to direct traditional teaching. Contradictory findings were seen in study conducted by Zalat $\mathrm{M}$ et al., where, majority of the participants preferred e-learning as it had the advantages of time flexibility of teaching the course. The major challenges for adapting to e-learning reported were unstable internet connectivity, lack of computers, laptops or other devices and technical.

The system of Problem Based Learning allowed early exposure to clinical scenarios and enabled them to develop professional skills through hypothetical cases. This method promotes student's interpersonal communication skills and their ability to work as a team. Working in groups also enhanced their understanding of complex concepts. Students who learned through this found learning to be stimulating and engaging, and showed better interpersonal skills and psychosocial knowledge as well as better attitudes towards patients as compared to those of traditional curriculum.

As per Begum $\mathrm{J}$ et al., $82 \%$ of students felt there is a significant need of interaction between students and teacher in a classroom. On comparing traditional vs interactive teaching modules, there was an increase in performance of students in the intervention group who received interactive training, which was statistically.

Mentorship programs are well-organized setting in which beneficial one to one relationships are developed between students and professionals. Karuna et al., studied the perceptions of students on mentoring programme and its impact on their medical education. According to the study, $97.8 \%$ of the participants had attended the mentoring sessions planned and $57 \%$ of the students benefitted from mentoring both academically and personally. $90.7 \%$ preferred one-to-one to group mentoring.

Though improvement in clinical skills was comparatively low in peer mentorship, mentees experienced increase in confidence, increased social support, interpersonal skills and more effective studying are some of its perceived benefits.

There is an increased awareness of the use of advanced teaching aids due to which traditional methods like chalk and board are becoming outmoded. Traditional Chalk and Board teaching is being considered as least effective. But study by Vadakedath et al., noted that a combination of CB and PPT with animations was preferred by majority of the students.

This traditional teaching method was most effective in small group teaching and modern aids like PowerPoint presentations were better suited for a larger group. A study by Wolf $A B$ et al., also concluded that during an online elearning class, the student's preferred Chalk and Board teaching videos rather than PowerPoint based alone.

Indian Medical Education system strives to train young medicos to become highly competent healthcare Professionals. This is achievable if students, faculty, administrators and all concerned parties co-operate. Just by following practices of developed countries without taking into account the local needs and priorities will cause a major setback the education system. New methods have to be adopted to keep up with the Competency Based Curriculum but traditions should not be abandoned entirely as they have their own benefits. The need of the hour is to embrace the contemporary teaching methods and incorporate it with the traditional methods to achieve the goal of a Competent Indian Medical Graduate. 


\section{References}

1. List of College Teaching MBBS. National Medical Commission. Available at: https://www.nmc.org.in/information-desk/forstudents-to-study-in-india/list-of-college-tea ching-mbbs/. Retrieved on 21.10.2021.

2. Vaughn L, Baker R. Teaching in the medical setting: balancing teaching styles, learning styles and teaching methods. Medical Teacher. 2001; 23(6):610-612.

3. Shah N, Desai C, Jorwekar G, Badyal D, Singh T. Competency-based medical education: An overview and application in pharmacology. Indian journal of pharmacology. 2016 Oct;48 (Suppl 1):S5.

4. Rao M S. The history of medicine in India and Burma. Medical history. 1968 Jan;12(1):5261.

5. Negandhi H, Sharma K, Zodpey S P. History and evolution of public health education in India. Indian Journal of Public Health. 2012 Jan 1;56(1):12.

6. Anshu A S. Evolution of medical education in India: The impact of colonialism. Journal of postgraduate medicine. 2016 Oct;62(4):255257.

7. Shahdad S, Khan M A. Chalk \& Board or Power Point Presentation - Students View towards Method of Teaching Anatomy. Sch. J. App. Med. Sci., Oct 2017; 5(10E):4155-4158

8. Editorial Team. What Is Didactic Teaching. Indeed career guide, June 2021. Accessed from: https://www.indeed.com/careeradvice/career-development/didacticteaching.Retrieved on: 28.10.2021

9. Al-Balas M, Al-Balas H I, Jaber H M, Obeidat $\mathrm{K}$, Al-Balas H, Aborajooh E A, Al-Taher R, Al-Balas B. Distance learning in clinical medical education amid COVID-19 pandemic in Jordan: current situation, challenges, and perspectives. BMC medical education. 2020 Dec;20(1):1-7.

10. Williams D E. The future of medical education: flipping the classroom and education technology. Ochsner J. 2016 Spring; 16(1): 14-15.

11. Petrovska, Sonja \& Sivevska, Despina \& Popeska, Biljana \& Runcheva, Jadranka. (2018). Mentoring in teaching profession.
International Journal of Cognitive Research in Science Engineering and Education. 6. 47-56. 10.5937/ijcrsee1802047P.

12. Muhammad Mussadiq K, Zarmina S, Fareed M, Idrees A, Afifa K, Farhan H. Innovation in medical education: implementation of problem based learning under the umbrella of a traditional curriculum-perceptions of students and faculty.

13. Bradley, Paul. (2006). The history of simulation in medical education and possible future directions. Medical education. 40. 25462. 10.1111/j.1365-2929.2006.02394.x.

14. Giorgdze, Madona \& Dgebuadze, Marine. (2017). Interactive teaching methods: challenges and perspectives. IJAEDUInternational E-Journal of Advances in Education. 544-548. 10.18768/ijaedu.370419.

15. Vadakedath S, Sudhakar T, Kandi V. Assessment of conventional teaching technique in the era of medical education technology: a study of biochemistry learning process among first year medical students using traditional chalk and board teaching. Am J Educ Res. 2018 Aug 13;6:1137-40.

16. Zalat M M, Hamed M S, Bolbol S A. The experiences, challenges, and acceptance of elearning as a tool for teaching during the COVID-19 pandemic among university medical staff. PloS one. 2021 Mar 26;16(3): $\mathrm{e} 0248758$.

17. Begum J, Ali S I, Panda M. Introduction of interactive teaching for undergraduate students in community medicine. Indian journal of community medicine: official publication of Indian Association of Preventive \& Social Medicine. 2020 Jan;45(1):72.

18. Sree, Karuna \& Lakshmi, Rajya \& Rao, Venkata \& Archana, A. D. \& Mohanty, Shruti. (2018). Mentoring in Medical Education: Impact on the Undergraduate Students. Journal of Research in Medical Education \& Ethics. $\quad 8.69 . \quad 10.5958 / 2231$ 6728.2018.00013.6.

19. Altonji S J, Baños J H, Harada C N. Perceived benefits of a peer mentoring program for firstyear medical students. Teaching and learning in medicine. 2019 Aug 8;31(4):445-52. 


\section{How to cite this article:}

Divya Reddy Pannala and Shyamala, R. 2021. Evolution of Teaching Methods in Medical Education Over the Years. Int.J.Curr.Microbiol.App.Sci. 10(11): 362-368.

doi: https://doi.org/10.20546/ijcmas.2021.1011.041 